\title{
Akım sitometrik ölçüm öncesi pre-analitik yöntem optimizasyonu ve postmenapozal süreçte immünfenotipleme örneği
} Pre-analytical method optimization for flow cytometric measurement and immunophenotyping example in post-menopausal rat

Mustafa Erinç Sitar ${ }^{1,2}$, Yaprak Dönmez Çakıl13,4

'Maltepe Üniversitesi, Tip Fakültesi, Tibbi Biyokimya Anabilim Dal, İstanbul, Türkiye

${ }^{2}$ Maltepe Üniversitesi, Deney Hayvanları Araştırma ve Uygulama Merkezi, İstanbul, Türkiye

${ }^{3}$ Maltepe Üniversitesi, Tip Fakültesi, Histoloji ve Embriyoloji Anabilim Dall, İstanbul, Türkiye

${ }^{4}$ Maltepe Üniversitesi, Kanser ve Kök Hücre Araştırma Merkezi, İstanbul, Türkiye

ORCID ID: MES 0000-0001-5114-8660
YDC 0000-0002-4605-1167

Gönderim Tarihi: 16 Aralık 2020, Kabul Tarihi: 23 Arallk 2020

\section{ÖZET}

Amaç: Akım sitometri tıpta geniş bir kullanım alanına sahiptir. Standartlaştırılmış ve tekrarlanabilir veriler üretilmesi amacı ile standart işlem prosedürleri kullanılmaktadır. Sıçan, immünolojik araştırmalar için yaygın olarak kullanılan bir deney hayvanı modelidir, ancak sıçan türlerindeki yayınlar sınırlı sayıdadır. Bu çalışmada postmenopozal dönemde olan 19 aylık bir Wistar sıçandan aynı anda alınan periferik kan örneklerin iki farklı pre-analitik yöntem ile akım sitometrik ölçümlere hazırlanması ve lenfosit yüzde oranlarının değerlendirilmesi amaçlanmıştır.

Materyal ve Metodlar: Periferik kan örneklerinden lizis veya yoğunluk gradyan santrifüj yöntemleriyle eritrositler uzaklaştırılmıştır. Uygun miktarda antikorlar ile $T, B$, doğal öldürücü (NK), T helper ve T sitotoksik hücreleri tanımlanmış, BD Accuri C6 + akım sitometride analiz edilmiş ve yüzde oranları belirlenmiştir.

Bulgular: Eritrositlerin lizis tamponu ve yoğunluk gradyanı santrifüjü ile uzaklaştırıldığı iki yöntem ile de lenfosit ve T hücre alt gruplarının yüzde oranları benzer olarak bulunmuştur. Her iki yöntem ile üretilen sonuçlar sağlıklı genç sıçan ile karşılaştırıldığında B hücrelerinde azalma ve NK hücrelerde artış olduğu gözlenmiştir.

Sonuç: Çalışmamızda kullanılan iki pre-analitik yöntemin de sıçan tam kanının immünfenotiplemesi için uygun olduğu düşünülmektedir.

Anahtar kelimeler: immünfenotipleme, akım sitometri, sıçan
Illetişim: Yaprak Dönmez Çakıl

Marmara Eğitim Köyü 34857 Maltepe / İstanbul

e-mail: yaprak.cakil@maltepe.edu.tr

\section{SUMMARY}

Aim: Flow cytometry has a wide range of applications in medicine. Standard operating procedures are used to produce standardized and reproducible data. The rat is a commonly used model for immunological research, yet publications in rat species are limited. This study aims to prepare samples taken from a 19-month-old Wistar rat in the postmenopausal period with two different pre-analytical methods for flow cytometric measurements and to analyse the lymphocyte subsets.

Material and Methods: Erythrocytes were removed from peripheral blood samples by lysis or density gradient centrifugation. With the appropriate amount of antibodies, $\mathrm{T}, \mathrm{B}, \mathrm{NK}, \mathrm{T}$ helper and $\mathrm{T}$ cytotoxic cells were identified in a $\mathrm{BD}$ Accuri C6+ flow cytometer and percentages of the respective cells were determined.

Results: Similar percentages of lymphocyte and T subsets were obtained when the erythrocytes were removed by lysis buffer or density gradient centrifugation. A decrease in B cells and an increase in NK cells compared to the healthy young rats were observed.

Conclusion: Both pre-analytical methods used in our study are thought to be suitable for immunophenotyping of rat whole blood.

Keywords: immunophenotyping, flow cytometry, rat 


\section{GiRiş}

Akım hücre ölçümü (akım sitometri, flow sitometri) rutin klinik pratikte çok sık kullanılan bir analitik ölçüm tekniğidir. Tarihsel gelişiminin başlangıcı 1950'lere kadar uzansa da, esasta 1980'lerde ortaya çıkan HIV / AIDS salgını, farklı hücre tiplerinin sayılmasının önemini arttırmış ve böylece klinik laboratuvarlarda kullanımı daha pratik ve hızı sonuç veren akım sitometrelerinin geliştirilmesine ön ayak olmuştur $(1,2)$. Akım hücre ölçerlerin planktonlardan bakterilere, lenfositlerden monositlere geniş bir örnek spektrumu olması yanında, hücre siklüsündan yüzey belirteçleri analizine kadar geniş uygulama alanları da mevcuttur. Ayrica, onlarca parametrenin tek seferde ve tek bir numuneden ölçümü, özellikli hücre ayırım tekniği ile istenen hücre popülasyonun saf ve izole bir şekilde ana örnekten ayrıştırılması imkanı yine bu teknikle araştırmacılara sunulabilmektedir (3). Akım sitometri ile spesifik bir antijenin varlığı her bir hücre için tek tek değerlendirilebilmekte ve bu bilgi lösemiler, lenfomalar, miyelodisplastik sendromlar ve diğer immün yetmezlikle ilişkili hastalıkların tanı ve takibinde sıklıkla kullanılmaktadır. Her geçen yıl gelişen teknoloji ile bu tekniğin hassasiyeti ve özgüllüğü artsa da, ölçüm öncesi numunelerin hazırlık aşamasında uygulanan basamaklar, cihaz kurulumu ve kantitatif analizlerin doğru yapılması en sonunda verilecek olan sonucun güvenilirliği ve karşılaştırılabilir verilerin oluşturulabilmesi için kritik önem taşımaktadır. Insan örnekleri ile farklı cihaz platformlarında tamamen standartlaştırılmış ve tekrarlanabilir veriler üretilmesi amacı ile standart işlem prosedürleri kullanılmaktadır $(1,4)$. Ancak, deney hayvanlarında laboratuvarda pre-analitik dönem olarak adlandırılan ölçüm öncesi örnek hazırlığını kapsayan aşama için yapılmış ve yöntem optimizasyonu sağlanmış çalışma sayısı oldukça azdır $(5,6)$. Bununla birlikte, deney hayvan modellerinde yapılan immünoloji çalışmaları her geçen gün artmakta ve bu çalışmalar klinik araştırmalar için belirleyici ve kritik öncü veriler sunmaktadır. Deney hayvanlarında yapılacak çalışmaların farklı tür, cinsiyet ve yaş gibi etkenlerle heterojenite kazanacağı ve bu tür çalışmaların klinik çalışmaların planlanmasını etkileyeceği unutulmamalıdır (7)

Sıçan fizyolojisinde 15-18 aylık dişi hayvanlar reprodüktif olarak post-menopozal döneme denk gelmektedir (8). Mevcut çalışmada, deney hayvanı olarak postmenopozal dönemde olan Wistar bir sıçandan aynı anda alınan örneklerin iki farklı pre-analitik örnek hazırlama metodu ile analiz edilmesi tercih edilmiştir. Bu iki yöntemden biri yoğunluk farkı santrifüj temelli, diğeri ise özel bir lizis tampon solüsyonu ile eritrositlerin parçalanarak ortamdan uzaklaştırılması esasına dayanmaktadır. Mevcut çalışmada primer iki amaç olarak olarak; metodların karşılaştırılması ve bununla birlikte postmenapozal dönemde olan bir sıçanın $T, B$, doğal öldürücü (NK) hücrelerinin oranları ile T helper/ T sitotoksik hücre oranlarının hesaplanması örneğinin sunulması amaçlanmıştır.

\section{MATERYAL VE METODLAR}

\section{Yoğunluk gradyan santrifüjü ile lenfosit izolasyonu:}

Örnekler alındıktan hemen sonra, $2 \mathrm{~mL}$ sıçan periferik kanı fosfat tamponlu salin (PBS) ile 1:1 oranında seyreltilmiş ve $2 \mathrm{~mL}$ Histopaque (1.077 g / mL, Sigma; USA) üzerine yavaşça yayılmıştır. Seyreltilmiş örnek, oda sıcaklığında 40 dakika 400 g'de santrifüj edilmiştir. Sonrasında mononükleer hücreleri içeren "buffy coat" tabakası plazma ve Histopaque arasından süpürülmeyle dikkatlice toplanmış ve \%1 fetal sığır serumu (FBS) içeren PBS ile iki kere yıkanmıştır. Yıkama sırasındaki $400 \mathrm{~g}$ 'de 5 dakika santrifüj sonrası pellet elde edilmiştir ve antikor inkübasyonu için \%1 FBS içeren PBS ile seyreltilmiştir.

\section{Lizis tamponu ile eritrositlerin uzaklaştırılması:}

$200 \mathrm{uL}$ periferik kan $2 \mathrm{~mL}$ seyreltilmiş lizis tamponu ile (BD FACS Lysing solution) 6-8 dakika oda Isısında ve karanlıkta inkübe edilmiştir. 250 g'de 5 dakika santrifüj sonrası ortaya çıkan süpernatant ortamdan uzaklaştırılmıştır. Ardından hücreler \%1 FBS içeren PBS ile iki kere yıkanmış ve $400 \mathrm{~g}$ 'de 5 dakika santrifüj ile antikor eklenebilmesi için tekrar pellet elde edilmiştir.

\section{Kullanılan antikorlar ve izotip kontroller:}

Çalışmamızda lenfosit alt grupları olan T, B ve doğal öldürücü (NK) hücrelerini tanımlamak için sırasıyla bu hücrelerdeki özgül antijenleri tanıyan anti-CD-3 APC, anti-CD45RA FITC ve anti-CD161a PE (BD Biosciences, USA) antikorları kullanılmıştır. Benzer şekilde, T hücre alt tipleri olan T helper hücreleri ve T sitotoksik hücrelerini belirlemek için ise sırasıyla anti-CD4 PE ve anti-CD8a FITC antikorları (BD Biosciences, USA) kullanılmıştır. Kullanılan antikorlar ve her birinin hedeflediği hücre tipi, konjuge florofor, klonu ve izotipi Tablo 1'de verilmiştir. Boyama özgüllügünü sağlamak için izotip kontroller kullanılmışıı (Tablo 1).

\section{BULGULAR}

Her iki yöntem ile elde edilen hücreler aynı anda öncelikle büyüklük ve granül yapısına göre ileri saçılım (forward scatter, FSC-A) ve yana saçlım (side scatter, SSC-A) dedektörleri aracılığıyla analiz edilmiş ve lenfosit kapısı belirlenmiştir (Şekil 1A ve 3A). Lenfosit kapısı, lenfosit alt gruplarını tanımlayan antikorlar kullanılarak geri kapılama tekniği (back-gating) ile doğrulanmıştır. Anti-CD3, anti-CD45RA ve anti-CD161a antikorları sırasıyla T, B ve NK hücre gruplarının tespiti ve yüzde oranı değerlendirmesini sağlamıştır. Eritrosit lizis 
yöntemi ile elde edilen $T$ hücreleri $\% 44,1$, B hücreleri $\% 6,8$ ve NK hücreleri \%14,1 olarak bulunmuştur (Şekil $1 \mathrm{~B}, \mathrm{C}$ ve D). Yoğunluk gradyan santrifüj metodunda ise $T$ hücreleri $\% 44,3, B$ hücreleri $\% 5$ ve NK hücreleri \%15,6 olarak bulunmuştur (Şekil 3 B, C ve D).

Tablo 1: Kullanılan antikorlar ve hedeflenen hücre tipleri, konjuge floroforlar, klonlar ve izotipler gösterilmiştir.

\begin{tabular}{|c|c|c|c|c|}
\hline Antikor & Hücre tipi & Florofor & Klon & Irotip \\
\hline Anti-rat $\mathrm{CD} 3$ antibody & T cell & APC & $1 F 4$ & Mouse IgM, $\mathrm{K}$ \\
\hline Anti-rat CD45RA antibody & B cell & FITC & OX-33 & Mouse IgGl, $\kappa$ \\
\hline Anti-rat CD16la antibody & NK cell & PE & $10 / 78$ & Mouse $\mathrm{Ig} \mathrm{Gl}, \mathrm{\kappa}$ \\
\hline \multirow[t]{3}{*}{ Rat T Lymphocyte Cocktail } & T cell & APC & $1 F 4$ & Mouse IgM, $\mathrm{K}$ \\
\hline & T (CD4) helper cell & PE & oX-35 & Mouse IgG2a, $\mathrm{k}$ \\
\hline & $\mathrm{T}\left(\mathrm{CDB} \mathrm{a}^{-}\right)$cytotoxic cell & FITC & OX-8 & Mouse $\mathrm{Ig} G \mathrm{l}, \mathrm{K}$ \\
\hline Isotype Control & - & APC & G155-228 & Mouse $\operatorname{Ig} \mathrm{M}, \mathrm{x}$ \\
\hline Isotype Control & - & FITC & MOPC-31C & Mouse $\mathrm{Ig} G \mathrm{l}, \mathrm{K}$ \\
\hline Isotype Control & - & PE & MOPC- $31 \mathrm{C}$ & Mouse $\mathrm{Ig} G \mathrm{l}, \mathrm{K}$ \\
\hline Isotype Control & - & PE & G155-178 & Mouse IgG2a, $\mathrm{k}$ \\
\hline
\end{tabular}

Anti-CD4 ve anti-CD8a antikorları ile $\mathrm{T}$ helper ve $T$ sitotoksik hücreleri tespit edilmiştir. $T$ helper hücreler CD3+/CD4+ iken, T sitotoksik hücreler CD3+/CD8a+'tir. Bu hücrelerin oranları eritrosit lizis metodunda sırasıyla \%41,2 ve \%56,7 (Şekil 1E), yoğunluk gradyan santrifüj metodunda ise \% 39,3 ve $\% 58,2$ olarak saptanmıştır (Şekil 3E). Her iki yöntem ile de antikorlara denk boyama özgüllüklerini kontrol etmek için hazırlanan izotip kontrollerinin sonuçları kabul edilir ve olumlu olarak değerlendirilmiştir (Şekil 2 $A, B, C, D, E$ ve Şekil 4A, B, C, D, E).

\section{TARTIŞMA}

Lenfoma ve lösemi immünotiplemesi ( $K L L$, $A L L$, $\mathrm{AML}, \mathrm{KML})$, kemoterapi etkinliğinin izlenmesi, diğer hematolojik hastalıkların belirlenmesi (nötrofil fonksiyon defektleri), kök hücre sayımı, otoimmün hastalıkların tanısı, HIV enfeksiyonu, allerjenlerin \& allerjik hastalıkların saptanması (bazofil degranülasyonu), trombosit analizi flow sitometrinin tıptaki geniş kullanım alanlarına verilen örneklerdir $(9,10)$. Aynı zamanda pre-klinik çalışmaların gerekliliği, sıçanı immünolojik araştırmalar için yaygın olarak kullanılan bir deney hayvanı modeli yapmaktadır. Ancak, deney hayvanlarında pre-analitik yöntem optimizasyonu, lökosit popülasyonlarının ve alt kümelerinin karakterizasyonu ile ilgili konularda insan örneklerine göre daha az sayıda çalışmaya rastlanmaktadır.
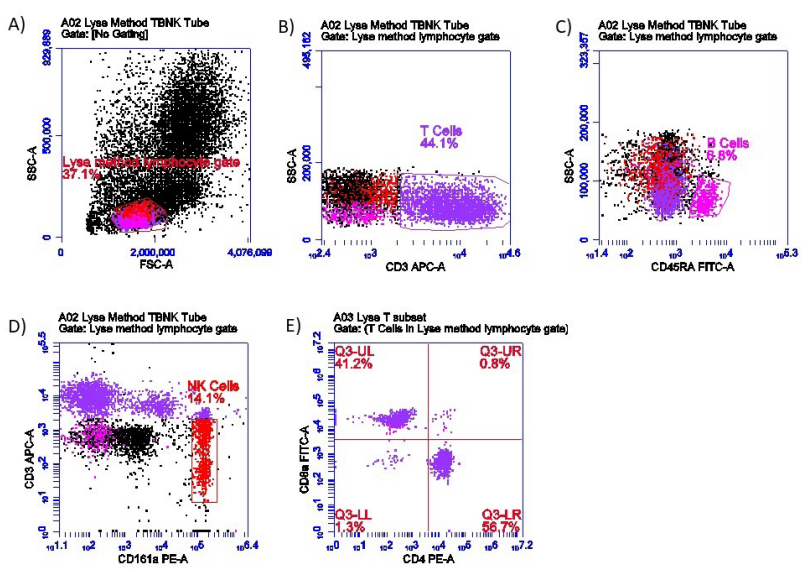

Sekil 1. Eritrosit lizis yöntemi ile lenfositler elde edilmiş, lenfosit kapısı belirlenmiş $(A)$ ve sırasıyla T, B ve NK hücre gruplarının yüzde oranları $(B, C$ ve $D)$ değerlendirilmiştir. Anti-CD4 ve anti-CD8a antikorları ile $T$ helper ve T sitotoksik hücreleri tespit edilmiştir (E).
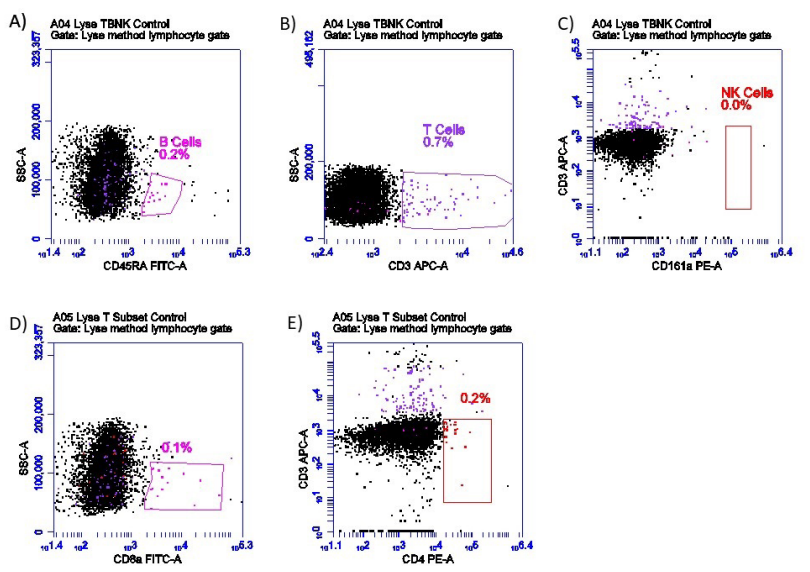

Şekil 2. Eritrosit lizis yöntemi ile elde edilen hücreler, antikorlara denk boyama özgüllüklerini kontrol etmek için hazırlanan izotip kontrolleri ile boyanmıştır. B hücreleri (A), T hücreleri (B), NK hücreleri (C), T sitotoksik hücreleri (D) ve $T$ helper hücrelerini (E) hedefleyen antikorlara karşılık gelen izotip kontroller ile yapılan boyamalar gösterilmiştir.
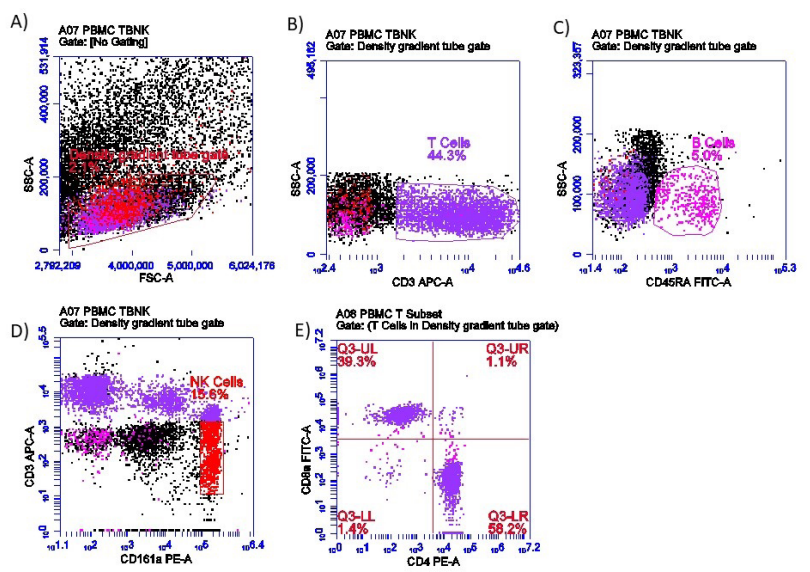

Sekil 3. Yoğunluk gradyan santrifüj yöntemi ile lenfositler elde edilmiş, lenfosit kapısı belirlenmiş $(A)$ ve sırasıyla T, B ve NK hücre gruplarının yüzde oranları (B,C ve D) değerlendirilmiştir. Anti-CD4 ve anti-CD8a antikorları ile $T$ helper ve $T$ sitotoksik hücreleri tespit edilmiştir (E). 

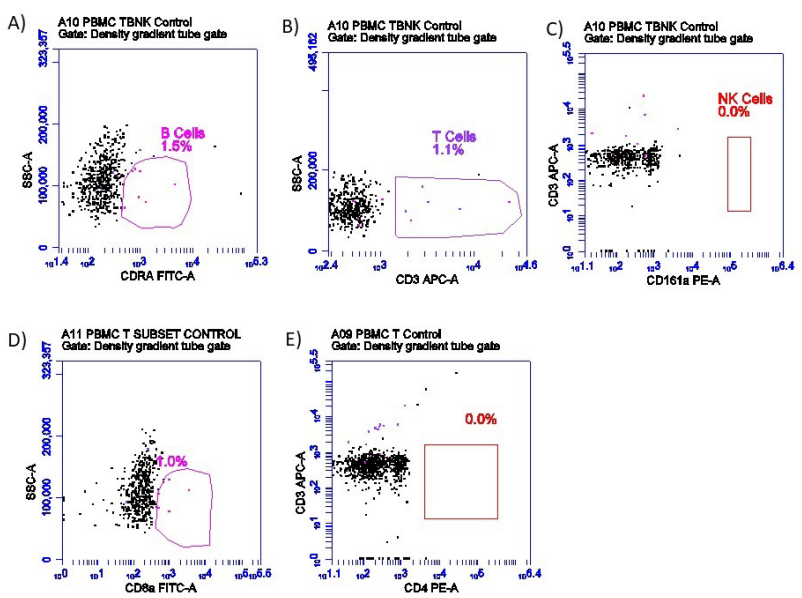

Şekil 4. Yoğunluk gradyan santrifüj yöntemi ile elde edilen hücreler, antikorlara denk boyama özgüllüklerini kontrol etmek için hazırlanan izotip kontrolleri ile boyanmıştır. B hücreleri (A), T hücreleri (B), NK hücreleri (C), T sitotoksik hücreleri (D) ve $T$ helper hücrelerini (E) hedefleyen antikorlara karşılık gelen izotip kontroller ile yapılan boyamalar gösterilmiştir.

Çalışmamızda, 19 aylık postmenopozal Wistar sıçanı tam kan örneği iki farklı pre-analitik yöntem ile hazırlanmış ve uygun antikorlarla işaretlenerek lenfosit alt tipleri görüntülenmiş, yüzde oranları karşılaştırılmıştır. Eritrositlerin lizis tamponu veya yoğunluk gradyanı santrifüjü ile uzaklaştırıldığı her iki yöntem ile de $T$, $B$ ve NK hücrelerinin ve $T$ hücre alt gruplarının ( $T$ helper hücreler ve $T$ sitotoksik hücreler) yüzde oranları birbirlerine yakın değerler olarak gözlenmiştir. Bu durum her iki pre-analitik yöntemin de sıçan tam kanının immünfenotiplemesi için kullanılabileceği görüşünü desteklemektedir.

Her iki yöntem ile elde edilen verilerin sağlıklı genç sıçanlardaki referans aralıklara göre değerlendirmesi yapıldığında, yaşlı kemirgenler için B hücrelerinde azalma ile NK hücrelerinde artış göze çarpmaktadır. Abbondanze ve Chang'ın 2014 yılında yaptıkları bir çalışmada, F344 türünde 18-20 aylık erkek sıçanda $\mathrm{T}$ hücre oranında ilerleyen yaşla birlikte belirgin bir değişim gözlenmezken, B hücre oranında düşüş dikkati çekmektedir (11). 46 Sprague-Dawley dişi ve erkek sıçanın dahil edildiği bir diğer çalışmada ise, artan yaş ile birlikte periferik kan B hücre sayısında bir değişim gözlenmemiştir (3- 26 ay arası) (12). Mevcut çalışma ile postmenopozal bir deney hayvanında immunfenotipleme için bir tablo ortaya konulmaktadır. Bu değerlerde kemirgenlerin türüne, yaşına, cinsiyetine (13) ve farklı diğer fizyolojik koşullarına göre farklılıklar olduğu unutulmamalıdır. Mevcut çalışmanın grup sayısı, tür ve yaş sınırlamalarını aşmak, ileride daha ayrıntılı bilgi edinilecek çalışmalar yapabilmek için yaşlı grup yanında genç hayvanların da olacağı, dişi cinsiyet yanında erkeklerin de dahil edileceği araştırmaların yapılması gerekmektedir. Ayrıca periferik kan yanında, kemik iliği, dalak ve timus yerleşimli lökositlerin de edilmesi gereken konular olabilir.

\section{Teşekkür ve araştırma fonu}

Bu çalışma Maltepe Üniversitesi Bilimsel Araştırma Projelerini Destekleme Birimi tarafından desteklenmiştir. Çalışmanın yürütülmesinde teknik ve altyapı desteği sağlayan Maltepe Üniversitesi Kanser ve Kök Hücre Merkezi ve Maltepe Üniversitesi Deney Hayvanları Uygulama ve Araştırma Merkezi'ne ayrıca teşekkür ederiz.

\section{KAYNAKLAR}

1. Cossarizza A, Chang HD, Radbruch A, Akdis M, Andrä I, Annunziato $F$, et al. Guidelines for the use of flow cytometry and cell sorting in immunological studies. European journal of immunology. 2017;47(10):1584797.

2. Melamed MR. A brief history of flow cytometry and sorting. Methods in cell biology. 2001;63:3-17.

3. Adan A, Alizada G, Kiraz Y, Baran Y, Nalbant A. Flow cytometry: basic principles and applications. Critical reviews in biotechnology. 2017;37(2):163-76.

4. Nováková $M$, Glier $H$, Brdičková $N$, Vlková $M$, Santos $A H$, Lima $M$, et al. How to make usage of the standardized EuroFlow 8-color protocols possible for instruments of different manufacturers. Journal of immunological methods. 2019;475:112388.

5. Alavi N, Khan SH, Saadia A, Naeem T. Challenges in preanalytical phase of laboratory medicine: rate of blood sample nonconformity in a tertiary care hospital. EJIFCC. 2020;31(1):21.

6. Bielohuby $M$, Popp S, Bidlingmaier $M$. A guide for measurement of circulating metabolic hormones in rodents: Pitfalls during the pre-analytical phase. Molecular metabolism. 2012;1(1-2):47-60.

7. Festing MF, Altman DG. Guidelines for the design and statistical analysis of experiments using laboratory animals. ILAR journal. 2002;43(4):244-58.

8. Sengupta $P$. The laboratory rat: relating its age with human's. International journal of preventive medicine. 2013;4(6):624.

9. Jaye DL, Bray RA, Gebel HM, Harris WA, Waller EK. Translational applications of flow cytometry in clinical practice. The Journal of Immunology. 2012;188(10):4715-9.

10. Kanegane $H$, Hoshino A, Okano T, Yasumi T, Wada $\mathrm{T}$, Takada $\mathrm{H}$, et al. Flow cytometry-based diagnosis of primary immunodeficiency diseases. Allergology International. 2018;67(1):43-54.

11. Abbondanzo SJ, Chang SL. HIV-1 transgenic rats display alterations in immunophenotype and cellular responses associated with aging. Plos one. 2014;9(8):e105256.

12. Flaherty DK, Wagner CA, Gross CJ, Panyik MA. Aging and lymphocyte subsets in the spleen 
and peripheral blood of the Sprague-Dawley rat. Immunopharmacology and immunotoxicology. 1997;19(2):185-95.

13. Ridge K, Downes N, Finney B. Effects of strain, sex and age on immunophenotyping parameters in the rat and mouse. Comparative Clinical Pathology. 2019;28(1):41-51. 